\title{
PENGARUH PROSES EVALUASI KINERJA TERHADAP PERSEPSI PROCEDURAL FAIRNESS: STUDI DI PERGURUAN TINGGI
}

\author{
Dian Wijayanti*1, Sendy Cahyadi ${ }^{2}$ \\ 1,2 Program Studi Akuntansi, Fakultas Ekonomi dan Bisnis, Universitas Ma Chung \\ Villa Puncak Tidar N-01, Malang, Jawa Timur \\ *Email Correspondence: wijayanti.dian@machung.ac.id
}

\begin{abstract}
This study aims to test the process of performance evaluation particularly the formality and participation may effect the procedural fairness. Research conducted in universities as educational institutions that prioritizes quality of education involving all work units. Survey method was apllied by distributing questionnaires to 70 educational staff. 55 questionnaires were returned and 47 questionnaires were qualified to be analyzed in this study. Regression analysis was applied withing the research to conduct hypothesis testing. The results exposes formalities of performance evaluation effects the perception of procedural fairness, yet participation does not effect the perception of procedural fairness. It may happen since respondents prefer to understand the right instrument in assessing performance in performance evaluation is more important than participation in evaluation. Being aware of the results from the research, the process of performance evaluation requires formalized practical implication in order to obtain fairness evaluation process for everyone in the organization.
\end{abstract}

Keywords: performance evaluation system, formality, participation, procedural fairness

\begin{abstract}
Abstrak
Penelitian ini dilaksanakan untuk mengetahui bahwa proses evaluasi kinerja khususnya mengenai formalitas dan partisipasi dapat mempengaruhi procedural fairness. Penelitian dilakukan di universitas sebagai lembaga penyelenggara pendidikan tingkat tinggi yang mengutamakan kualitas pada berbagai bidang studi yang ada. Untuk mendapatkan hasil yang diinginkan, survey dibuat dengan membagikan 70 kuesioner kepada seluruh tenaga kependidikan di universitas. Dari jumlah tersebut terkumpul 55 data survey dengan 47 data yang valid untuk digunakan dalam menyelesaikan penelitian, sedangkan pengujian hipotesa dalam penelitian ini menggunakan analisa regresi. Hasil penelitian menunjukkan bahwa formalitas pada evaluasi kinerja mempengaruhi persepsi dari procedural fairness, akan tetapi partisipasi tidak berpengaruh pada persepsi dari procedural fairness. Hal ini dikarenakan para responden berpikir bahwa instrumen yang tepat lebih penting daripada partisipasi. Dari hasil yang didapatkan, diharapkan peningkatan evaluasi kinerja yang lebih terstruktur khususnya untuk setiap individu dalam organisasi agar merasakan persamaan dan keadilan proses evaluasi.

Kata Kunci: sistem evaluasi kinerja, formalitas, partisipasi,procedural fairness
\end{abstract}

\section{PENDAHULUAN}

Sistem evaluasi kinerja masih menjadi topik yang mendominasi dalam penelitian akuntansi manajemen (Harris \& Durden, 2012). Lebih lanjut Harris \& Durden (2012) menjelaskan bahwa sistem evaluasi kinerja masih menjadi pusat dalam praktik dan penelitian akuntansi manajemen. Oleh karena itu topik sistem evaluasi kinerja masih relevan untuk dikaji lebih mendalam dengan tidak hanya melihat aspek pengukuran kinerja saja tetapi juga proses evaluasi kinerja, yang dalam hal ini terkait dengan bagaimana evaluasi kinerja dilakukan oleh atasan. Sistem evaluasi kinerja pun berkembang tidak hanya mempertimbangkan informasi finansial atau akuntansi namun juga informasi nonfinansial sebagai pengukuran kinerja. Hal tersebut dikaji oleh Franco- 
Santos, dkk. (2012) dengan mengembangkan rerangka konseptual untuk memahami konsekuensi sistem pengukuran kinerja kontemporer yang terdiri atas pengukuran kinerja finansial dan nonfinansial dan teori yang mendasari konsekuensi ini.

Literatur-literatur organisasional mengatakan bahwa partisipan dalam organisasi membentuk persepsi tentang fairness tentang prosedur yang dilakukan organisasi terhadap mereka, kemudian persepsi ini akan dapat menjelaskan luaran pekerjaan yang penting, seperti motivasi, komitmen, dan kinerja tugas (Hartmann \& Slapnicar, 2012). Salah satu prosedur dalam organisasi yang dipersepsikan fair dalam hal ini adalah praktik evaluasi kinerja. Hartmann \& Slapnicar (2012) mengatakan pula bahwa karakteristik yang menyebabkan evaluasi kinerja dipersepsikan fair masih terbatas.

Secara normatif prinsip procedural fairness terdiri atas konsistensi dan akurasi. Oleh sebab itu, atasan yang bersikap konsisten dan akurat dalam memberikan evaluasi kinerja akan dinilai lebih fair dalam proses evaluasi. Namun, Hartmann \& Slapnicar (2012) mengatakan bahwa masih sedikit literatur yang menjelaskan perilaku atau prosedur aktual apa yang dapat meningkatkan konsistensi dan akurasi untuk mencapai fairness. Kurangnya dasar teoretis mengakibatkan penelitian terdahulu memberikan prediksi pengaruh fairness terhadap karateristik evaluasi kinerja yang tidak konsisten. Karakteristik evaluasi kinerja dalam hal ini sebagai contoh adalah ukuran non-finansial yang dianggap lebih akurat namun tidak konsisten.

Penelitian ini mencoba melihat evaluasi kinerja bukan dari metriks pengukurannya (finansial dan non-finansial) namun lebih pada proses evaluasi kinerja itu dilakukan dalam organisasi. Trade-off yang terjadi antara konsistensi dan akurasi menyebabkan fairness tidak lagi dilihat dari pengukuran evaluasi kinerja namun dari proses evaluasi kinerja. Karakteristik proses evaluasi meliputi formalitas evaluasi kinerja dan partisipasi bawahan dalam proses evaluasi. Penelitian ini mencoba menguji pengaruh proses evaluasi kinerja terhadap persepsi prosedural fairness.

Penting bagi organisasi untuk mendesain evaluasi kinerja sesuai dengan tujuan organisasi dan menggunakannya untuk mencapai tujuan stategis organisasi. Telah dipaparkan bahwa desain evaluasi kinerja telah berkembang seiring dengan berkembangnya organisasi dan dipengaruhi oleh budaya maupun perilaku individu dalam organisasi. Hal ini dilihat dari penelitian-penelitian terkini yang semakin luas mengkaji evaluasi kinerja tidak hanya dari aspek organisasi namun individu di dalamnya.

Penelitian mengenai proses evaluasi kinerja dikembangkan pertama kali oleh Hartmann \& Slapnicar (2009) yang menguji formalitas evaluasi kinerja memengaruhi kepercayaan individu terhadap atasannya. Hartmann dan Slapnicar $(2009,2012)$ melihat evaluasi kinerja tidak dari metrik pengukuran kinerja akan tetapi dari proses evaluasi kinerja yang dalam hal ini adalah tingkat formalitas evaluasi kinerja dalam organisasi dan peran partisipasi bawahan (voice). 
Hartmann dan Slapnicar (2009) menguji pengaruh proses evaluasi kinerja, yaitu tingkat formalitas, terhadap kepercayaan melalui persepsi procedural fairness dan kualitas umpan balik. Hartmann dan Slapnicar (2012) menambahkan karakteristik dalam proses evaluasi kinerja yaitu tidak hanya tingkat formalitas, namun juga adanya partisipasi bawahan (voice). Kedua karakteristik proses evaluasi diuji pengaruhnya terhadap persepsi procedural fairness. Hasil penelitian Hartmann dan Slapnicar (2012) menunjukkan bahwa dalam kondisi yang tidak pasti, voice lebih signifikan mempengaruhi procedural fairness.

Replikasi dilakukan dalam penelitian ini dengan menguji tingkat generalisasi temuan penelitian sebelumnya pada konteks yang berbeda. Seperti yang dikatakan Leung (2005) dalam Agritansia \& Sholihin (2011) bahwa prosedural fairness masih perlu diuji dalam berbagai konteks. Hal ini mengisyaratkan bahwa pengaruh prosedural fairness tidak dapat digeneralisasi dalam segala konteks. Penelitian sebelumnya, Hartmann \& Slapnicar (2012) menguji pengaruh proses evaluasi kinerja dalam industri perbankan. Hasil penelitiannya menunjukkan partisipasi (voice) memengaruhi persepsi prosedural fairness.

Persepsi fairness dapat memberikan dampak kepada perilaku individu dalam menjalankan pekerjaannya. Semakin tinggi persepsi fairness maka akan meningkatkan motivasi, komitmen dan kinerja. Oleh karena itu penelitian ini mencoba mengonfirmasi prediksi bahwa proses evaluasi kinerja berpengaruh pada persepsi fairness. Penelitian dilakukan di Perguruan Tinggi Ma Chung dengan pertimbangan sistem evaluasi telah dibangun untuk menilai kinerja karyawan dan dosen. Namun, sampai saat ini masih belum dilakukan upaya evaluasi sejauh mana evaluasi kinerja ini dinilai fair oleh karyawan sehingga dapat meningkatkan motivasi dan komitmen mereka. Pengujian ini diharapkan memberikan hasil bahwa proses evaluasi kinerja yang tepat dapat menghasilkan penilaian fair dari karyawan yang akan meningkatkan motivasi dan komitmen.

Sistem evaluasi kinerja menjadi penting karena dapat mengukur bagaimana karyawan melakukan pekerjaannya sesuai dengan yang diinginkan oleh organisasi. Namun, sistem evaluasi yang dapat memberikan kontribusi dalam peningkatan motivasi, komitmen dan kinerja, juga harus dinilai fair oleh karyawan. Dalam konteks organisasi yang bergerak di bidang pendidikan, sistem evaluasi kinerja yang sesuai memberikan kontribusi dalam peningkatan kualitas pendidikan. Baik dari segi suasana akademik, sarana dan prasarana yang disediakan maupun kegiatan utama pembelajaran kepada mahasiswa.

Secara umum penelitian ini bertujuan untuk menilai persepsi prosedural fairness dalam proses evaluasi kinerja yang dapat memberi masukan kepada pimpinan organisasi untuk membangun rerangka sistem evaluasi kinerja yang dapat meningkatkan motivasi, komitmen dan kinerja individu. Lebih khusus, proses evaluasi kinerja itu meliputi formalitas dan adanya 
partisipasi bawahan dalam membangun sistem evaluasi kinerja. Lebih jauh terkait dengan penilaian kinerja karyawan di instansi pendidikan, persepsi fairness dalam penilaian kinerja dipandang penting untuk menilai proses penilaian yang mengedepankan peningkatan kualitas, yang akan berdampak pada kualitas layanan pendidikan.

\section{TELAAH LITERATUR}

\section{Persepsi Fairness}

Teori organizational justice menjelaskan tentang persepsi keadilan (Voubem, Kramer, \& Schaffer, 2016). Dua bentuk persepsi keadilan yang dibedakan dalam teori keadilan organisasi adalah distributive justice dan procedural justice (Greenberg, 1987). Distributive justice menyangkut pencapaian yang dicapai, sedangkan procedural justice adalah tentang keadilan dalam prosedur yang digunakan untuk menentukan hasil tersebut (Greenberg, 1987).

Procedural fairness merujuk pada konsekuensi psikologis sosial dari variasi keadilan, yang menitikberatkan pada efek prosedur pada penilaian keadilan (Thibaut dan Walker, 1975 dalam Lau dan Moser, 2008). Dijelaskan pula bahwa (1) persepsi procedural fairness akan meningkatkan kepuasan, (2) procedural fairness adalah penentu yang paling penting dalam pilihan prosedur, dan (3) prosedur pengendalian proses yang tinggi akan membawa pada penilaian keadilan yang tinggi juga. Terkait dengan pengukuran kinerja, bawahan akan menilai evaluasi kinerjanya fair jika (1) penilaian kinerja yang berdasar informasi yang akuran dan lengkap, (2) merefleksikan kepentingan jangka panjang, (3) mengandung ketentuan yang menolak penilaian unfair, (4) merefleksikan kinerja yang dalam pengendalian, (5) melindungi kepentingannya, dan (6) mengindikasikan perlakukan yang sopan dan pantas (Lau

Prosedur akan dipersepsikan fair ketika konsisten sepanjang waktu dan antar individu, terbebas dari bias, akurat, berisi mekanisma untuk memperbaiki keputusan yang salah, melekat dengan konsep moralitas umum, dan mewakili pendapat individu yang terlibat. Sistem pengendalian manajemen memiliki aspek procedural fairness karena sistem pengendalian manajemen berdasarkan prosedur yang mendefinisikan seberapa obyektif ditetapkan, pengukuran kinerja dan pemberian penghargaan (Langevin dan Mendoza, 2013).

Penelitian sebelumnya telah menguji pengaruh procedural fairness terhadap perilaku individu yang akan meningkatkan kinerjanya. Namun, pengaruhnya bervariasi baik langsung maupun tidak langsung (Supriyadi, 2010). Procedural fairness pada evaluasi kinerja mempengaruhi kepuasan kerja melalui tingkat kepercayaan terhadap atasan, komitmen organisasi, dan fairness of outcome (Lau, dkk., 2008). Model dalam penelitian ini diuji kembali dengan menggunakan subyek yang berbeda untuk menilai generalisasi hasil penelitian oleh Sholihin dan Pike (2009). Hasilnya menunjukkan tidak ada perbedaan dengan penelitian 
sebelumnya oleh Lau, dkk. (2008). Namun demikian, terdapat hasil yang tidak konsisten pengujian pengaruh pengukuran kinerja pada persepsi procedural fairness. Sedangkan Lau dan Moser (2008) mengindikasikan bahwa persepsi procedural fairness manajer lebih fair pada pengukuran kinerja nonfinansial karena dipandang lebih lengkap dan akurat. Salah satu alasan yang mungkin dari ketidak konsistenan penelitian ini adalah pentingnya proses penilaian kinerja.

\section{Formalitas Evaluasi Kinerja}

Konstruk formalitas evaluasi kinerja pertama kali dibangun dari penelitian Hartmann dan Slapnicar (2009) yang menguji model hubungan yang terkait dengan sistem evaluasi kinerja yang dipakai oleh atasan dengan kepercayaan bawahan. Konstruk formalitas terkait evaluasi kinerja dikembangkan oleh Hartmann dan Slapnicar (2009) karena menurut mereka penelitian sebelumnya memberikan bukti bahwa sistem evaluasi kinerja memiliki potensi berdampak pada kepercayaan, namun juga menimbulkan pertanyaan mengenai aspek sistem evaluasi kinerja mana yang mempengaruhi kepercayaan dan bagaimana pengaruhnya. Maka, Hartmann dan Slapnicar (2009) menguji dari aspek proses evaluasi kinerja yaitu seberapa formal evaluasi kinerja dilakukan dalam sebuah organisasi.

Proses Evaluasi Kinerja dalam penelitian ini merujuk pada proses evaluasi kinerja yang dikemukakan Hartmann \& Slapnicar $(2009,2012)$. Evaluasi kinerja ini dilihat oleh formalitas seperti yang digambarkan sebagai seberapa besar objektivitas (dibandingkan dengan subjektivitas) dalam proses evaluasi kinerja. Seorang atasan yang sering secara informal mengevaluasi kinerja dengan menggunakan target kualitatif daripada kuantitatif, mengukur kinerja berdasarkan penilaian kualitatif dan bukan prosedur yang dilacak, dan sering mendasarkan penilaian berbasis penghargaan daripada fakta dokumennya (Moers, 2005). Atasan yang secara informal mengevaluasi bawahan cenderung menggunakan target kualitatif seperti 'lakukan yang terbaik' dibandingkan dengan menggunakan target yang terdokumentasi dengan baik (Hartmann \& Slapnicar, 2012).

Definisi formalitas dalam penelitian ini mengikuti definisi yang diajukan oleh Hartmann \& Slapnicar (2009). Untuk tingkat proses evaluasi kinerja yang berbeda, formalitas didefinisikan sebagai berikut, (1) terkait penentuan target, yang menyiratkan semakin tinggi tingkat formalitas berarti atasan menjelaskan dan menetapkan target dalam bentuk kuantitatif dan tertulis, sementara menargetkan cara informal menetapkan target secara implisit, kualitatif dan dikomunikasikan secara informal, (2) terkait dengan pengukuran kinerja, semakin tinggi tingkat formalitas yang memerlukan ukuran kinerja yang lebih objektif dan kuantitatif daripada pengukuran subjektif dan kualitatif, yang lebih pada pengukuran kinerja informal, dan (3), terkait dengan penghargaan, semakin tinggi tingkat formalitas menunjukkan bahwa ada ketentuan atau 
rumusan dalam menentukan bonus atau imbalan, sementara proses informal menggunakan pertimbangan pribadi dalam menentukan bonus.

\section{Partisipasi dalam Evaluasi Kinerja (Voice)}

Hartmann dan Slapnicar (2012) mengusulkan karakteristik kedua dalam proses evaluasi kinerja, yaitu mengarah pada partisipasi bawahan dalam proses evaluasi kinerja. Hartmann dan Slapnicar (2012) mengemukakan karakteristik patisipasi dalam proses evaluasi kinerja dengan tujuan untuk meningkatkan konsistensi dan akurasi dalam proses evaluasi kinerja. Partisipasi didefinisikan menurut Leventhal (1980) dalam Libby (1999) adalah kemampuan bawahan terlibat dalam proses pengambilan keputusan dengan mengomunikasikan pandangan mereka kepada atasannya. Voice dalam penelitian sebelumnya digunakan untuk menguji persepsi keadilan dalam setting penganggaran seperti yang dilakukan Libby (1999) dan Lindquist (1995).

Voice juga terkait dengan proses penganggaran yang artinya adanya partisipasi dalam proses penganggaran. Penelitian tentang penganggaran partisipatif telah dilakukan selama lebih dari 40 tahun dan memberikan bukti yang tidak konsisten mengenai pengaruhnya terhadap kepuasan dan kinerja (Lindquist, 1995; Shield \& Shield, 1998). Karena inkonsistensi ini, Lindquist (1995) dan Shield \& Shield (1998) mencoba memusatkan perhatian pada pendahuluan penganggaran partisipatif sehingga dapat menjelaskan kaitannya dengan konsekuensi penganggaran partisipatif, seperti kinerja dan kepuasan. Partisipasi tumbuh tidak hanya dalam konteks penentuan anggaran tetapi juga konteks pengukuran kinerja finansial dan non finansial. Penelitian oleh Sholihin, dkk. (2011) mengembangkan partisipasi tidak hanya dalam penetapan tujuan keuangan seperti Wentzel (2002) melakukannya tetapi juga dalam penetapan tujuan nonkeuangan. Hasil penelitian menunjukkan bahwa partisipasi dalam penetapan tujuan keuangan dan non keuangan mempengaruhi komitmen yang dimediasi oleh persepsi keadilan prosedural dan kepercayaan.

\section{Pengembangan Hipotesis}

Hopwood (1972) mengawali studi tentang evaluasi kinerja dengan menguji peran data akuntansi dalam evaluasi kinerja. Dalam hal ini Hopwood (1972) mengungkapkan bahwa atasan menggunakan informasi akuntansi yang dianggap sebagai sumber informasi formal dalam mengevaluasi kinerja bawahan. Sistem evaluasi kinerja pun berkembang tidak hanya mempertimbangkan informasi finansial atau akuntansi namun juga informasi nonfinansial sebagai pengukuran kinerja. Hal tersebut dikaji oleh Franco-Santos, dkk. (2012) dengan mengembangkan rerangka konseptual untuk memahami konsekuensi sistem pengukuran kinerja kontemporer yang terdiri atas pengukuran kinerja finansial dan nonfinansial dan teori yang mendasari konsekuensi ini. 
Pengaruh Proses Evaluasi Kinerja..

Beberapa penelitian sebelumnya telah mengkaji pengaruh evaluasi kinerja terhadap konsekuensi perilaku individu dari metriks pengkuran yang digunakan. Lau dan Buckland (2001) menguji pengaruh pengukuran kinerja yang melibatkan ukuran finansial terhadap tekanan pekerjaan melalui kepercayaan dan partisipasi. Hasil penelitian Lau dan Buckland (2001) mengisyaratkan bahwa pengukuran kinerja yang menitikberatkan pada pengukuran finansial secara tidak langsung mempengaruhi tekanan pekerjaan melalui kepercayaan dan partisipasi. Lau dan Sholihin (2005) menguji pengaruh ukuran nonfinansial terhadap kepuasan kerja melalui persepsi keadilan dan kepercayaan. Hasil yang penting pada penelitian Lau dan Sholihin (2005) adalah bahwa pengukuran kinerja nonfinansial memiliki pengaruh terhadap kepuasan kerja yang tidak berbeda dengan pengukuran kinerja finansial. Hall (2008) menguji pengaruh sistem pengukuran kinerja komprehensif/comprehensive performance measurement system terhadap kinerja melalui kejelasan peranan (role clarity) dan psychological empowerment. Penelitian ini menggarisbawahi peranan mekanisme kognitif dan motivasional dalam menjelaskan pengaruh sistem akuntansi manajemen terhadap kinerja manajerial.

Hartmann \& Slapnicar $(2009,2012)$ melihat evaluasi kinerja tidak dari metrik pengukuran kinerja akan tetapi dari proses evaluasi kinerja yang dalam hal ini adalah tingkat formalitas evaluasi kinerja dalam organisasi dan peran partisipasi bawahan (voice). Hartmann \& Slapnicar (2009) menguji pengaruh proses evaluasi kinerja, yaitu tingkat formalitas, terhadap kepercayaan melalui persepsi procedural fairness dan kualitas umpan balik. Hartmann \& Slapnicar (2012) menambahkan karakteristik dalam proses evaluasi kinerja yaitu tidak hanya tingkat formalitas, namun juga adanya partisipasi bawahan (voice). Kedua karakteristik proses evaluasi diuji pengaruhnya terhadap persepsi procedural fairness. Hasil penelitian Hartmann \& Slapnicar (2012) menunjukkan bahwa dalam kondisi yang tidak pasti, voice lebih signifikan mempengaruhi procedural fairness.

Penelitian ini menduga bahwa pendekatan formal dalam evaluasi kinerja akan mempengaruhi persepsi procedural fairness ketika bawahan diberikan kesempatan berpartisipasi dalam proses evaluasi kinerja. Formalitas akan dapat membantu meningkatkan konsistensi, sedangkan voice diharapkan dapat meningkatkan akurasi dalam proses evaluasi kinerja karena adanya keyakinan bahwa bawahan lebih mampu mengendalikan outcome proses (Hartmann \& Slapnicar, 2012). Langevin dan Mendoza (2013) juga berpendapat bahwa adanya kesempatan berpartisipasi merupakan alat komunikasi antara bawahan dan atasan yang memampukan bawahan untuk bertukar dan mencari informasi dari atasan. Sharing informasi dalam partisipasi akan meningkatkan akurasi data yang digunakan dalam proses pengambilan keputusan. Oleh karena itu hipotesis dalam penelitian ini dikemukakan sebagai berikut. 
H1: formalitas memengaruhi persepsi procedural fairness

H2: partisipasi dalam evaluasi kinerja memengaruhi persepsi procedural fairness

\section{METODE PENELITIAN}

Tahapan penelitian ini meliputi studi awal dengan melakukan observasi dan diskusi kelompok terfokus dengan pimpinan unit untuk membahas mekanisma evaluasi kinerja untuk mendapatkan gambaran menyeluruh terkait proses evaluasi kinerja. tahap berikut adalah pengambilan data penelitian dengan menyebarkan kuesioner kepada responden yang sesuai dengan metoda penyampelan yang dipilih. Data yang diperoleh diolah dan dianalisa untuk memperoleh hasil yang menjawab pertanyaan penelitian.

Pengujian awal dilakukan dengan tujuan untuk mendapatkan gambaran secara lengkap bagaimana proses evaluasi kinerja di Perguruan Tinggi. Tujuan kedua adalah untuk pengujian instrument penelitian agar dapat dipahami dan disesuaikan konteksnya dengan kondisi di institusi. Hasil yang diharapkan dari pengujian awal adalah mendapatkan gambaran kondisi pengukuran kinerja di institusi dan mendapatkan alat ukur variabel yang dapat dipahami dan tidak bias.

Penelitian ini dilakukan dengan metoda survey dengan cara menyebarkan kuesioner kepada tenaga kependidikan di sebuah Perguruan Tinggi. Alasan dipilihnya metoda survey adalah karena dua pertimbangan. Pertama, tidak ada arsip data public tentang konstruk yang dipakai dalam penelitian ini. Kedua, studi tentang fairness biasanya dianggap sebagai rahasia pribadi, yang mengharuskan bahwa pengumpulan data menjadi anonym, hal ini mudah dicapai dengan metoda survey (Hartmann \& Slapnicar, 2009).

Kuesioner disebarkan kepada 70 tenaga kependidikan di tiga Fakultas (Fakultas Ekonomi dan Bisnis, Fakultas Bahasa dan Seni, dan Fakultas Sains dan Teknologi), Lembaga Penelitian dan Pengabdian Masyarakat, Unit Pelaksana Teknis (Perpustakaan, dan Sistem Informasi), Biro Pendidikan, Biro Sumber Daya dan Keuangan, Biro Kemahasiswaan Pendidikan Karakter dan Kepemimpinan, Biro Kerjasama dan Pemasaran. Kuesioner disebarkan dengan mendatangi tenaga kependidikan di ruangan masing-masing. Kuesioner diserahkan kemudian diberi tenggat waktu pengisian. Saat ini proses pengambilan data masih di tahap penyebaran dan menunggu pengembalian kuesioner. Setelah kuesioner dikirimkan, maka peneliti akan mengirimkan pengingat melalui surel setiap 2 minggu dan mengunjungi responden di lingkungan tempat mereka bekerja.

Sebanyak 70 responden sesuai menjadi responden dalam penelitian ini, dan sebanyak 55 responden mengembalikan kuesioner, dalam hal ini tingkat pengembalian 78,8\%. Dari 50 kuesioner yang kembali, sebanyak delapan kuesioner tidak terpakai karena isiannya tidak 
lengkap. Dengan demikian, sebanyak 85,45\% kuesioner terpakai dari yang kembali. Berikut tabel responden

Tabel 1. Profil Responden

\begin{tabular}{|c|c|c|c|}
\hline \multicolumn{2}{|c|}{ Profil Responden } & \multirow{2}{*}{$\begin{array}{l}\text { Frekuensi } \\
10\end{array}$} & \multirow{2}{*}{$\begin{array}{l}\text { Persentase } \\
21,27 \%\end{array}$} \\
\hline Jabatan & Kepala Subbagian & & \\
\hline \multirow{4}{*}{ Tingkat pendidikan } & Kepala urusan/staf & 37 & $78,73 \%$ \\
\hline & S2 & 11 & $23,4 \%$ \\
\hline & $\mathrm{S} 1$ & 26 & $55,31 \%$ \\
\hline & SMA & 10 & $21,27 \%$ \\
\hline \multirow[t]{3}{*}{ Masa Kerja } & $>6$ tahun & 21 & $44,68 \%$ \\
\hline & 3-6 tahun & 8 & $17,02 \%$ \\
\hline & 1-3 tahun & 18 & $38,29 \%$ \\
\hline
\end{tabular}

Dari 47 kuesioner yang digunakan, terdapat 10 responden $(21,27 \%)$ menjabat kepala subbagian atau di atasnya, dan $37(78,73 \%)$ responden di posisi staf atau kepala urusan. Berdasarkan tingkat pendidikan, 26 responden (55,31\%) berpendidikan akhir S1, 11 responden $(23,4 \%)$ S2, dan 10 responden (21,27\%) SMA. berdasarkan lama bekerja, ada 3 kelompok lama bekerja, 1-3 tahun, 3-6 tahum dan lebih dari 6 tahun. terdapat 18 responden (38,29\%) dengan masa kerja 1-3 tahun, 8 responden (17,02\%) dengan masa kerja 3-6 tahun dan 21 responden $(44,68 \%)$ dengan masa kerja lebih dari 6 tahun.

\section{Variabel Penelitian}

Variabel independen dalam penelitian yaitu formalitas dan partisipasi. Varibel formalitas sistem evaluasi kinerja diukur dengan menggunakan instrument yang dikembangkan Hartmann \& Slapnicar (2009). Instrumen ini mengukur sistem evaluasi kinerja sebagai konstruk laten. Konstruk ini dikembangkan menjadi tiga sub sistem formalitas yang berbeda sebagai berikut: 1) formalitas target setting diukur menggunakan dua item pertanyaan apakah target setting dibuat oleh atasan dalam bentuk tertulis dan kuantitatif (lebih formal) atau sebaliknya, 2) formalitas pengukuran kinerja menggunakan dua item pertanyaan mengenai cara atasan melakukan penilaian kinerja apakah berdasarkan informasi obyektif dan kuantitatif (lebih formal) atau sebaliknya menggunakan penilaian pribadi dan bersifat kualitatif (kurang formal), 3) formalitas rewarding diukur dengan 4 item yang menunjukkan obyektivitas penentuan reward. Seluruh instrumen ini dinyatakan dalam skala likert 5 poin dengan penskalaan numerikal, yang dalam hal ini semakin mendekati 1 berarti kurang formal, dan sebaliknya semakin mendekati 5 berarti lebih formal.

Partisipasi dalam evaluasi kinerja diukur dengan menggunakan instrumen yang dikembangkan oleh Hartmann \& Slapnicar (2012). Partisipasi dalam penelitian ini adalah sejauh 
mana individu diijinkan untuk berperan dalam menentukan sasaran, dan secara aktif memberikan umpan balik dalam proses evaluasi kinerja. Tiga item pertanyaan dikembangkan yaitu (1) menanyakan apakah tujuan kerja ditentukan dengan mempertimbangkan masukan bawahan, (2) apakah ketika atasan menilai kinerja, memerhatikan penjelasan bawahan, dan (3) apakah ketika menentukan tujuan kerja atasan mempertimbangkan faktor yang tidak dapat dikendalikan.

Variabel dependen dalam penelitian ini adalah prosedural fairness yang diukur dengan empat item pertanyaan yang dikembangkan Hartmann \& Slapnicar (2009). Item pertanyaan meliputi sejauh mana responden percaya bahwa subsistem dari target setting, pengukuran kinerja dan rewarding, serta sistem secara keseluruhan, mengarah ke penentuan gaji yang fair.

Untuk mengetahui apakah instrumen variabel telah mengukur apa yang seharusnya diukur maka uji validitas dilakukan dengan menggunakan korelasi Uji validitas dilakukan untuk mengetahui apakah alat ukur variabel yang telah dirancang dalam bentuk kuesioner tersebut mengukur apa yang seharusnya diukur. Metode yang digunakan untuk menguji validitas dalam penelitian ini menggunakan korelasi product moment. Untuk menentukan apakah item pertanyaan valid atau tidak, maka nila $r$ hitung dibandingkan dengan nilai $r$ tabel yang dalam hal ini diperoleh nilai 0.2816 . Jika $r$ hitung lebih besar dari $r$ tabel maka item pertanyaan valid. Berikut hasil uji validitas untuk masing-masing instrument variabel.

\section{Tabel 2. Validitas Instrumen}

\begin{tabular}{l|rrr}
\multicolumn{1}{l}{ Variabel } & Item & \multicolumn{1}{c}{ Nilai $r$} & Keterangan \\
\hline Formalitas & Item 1 & 0.654 & Valid \\
& item 2 & 0.374 & Valid \\
& Item 3 & 0.779 & Valid \\
& Item 4 & 0.628 & Valid \\
& Item 5 & 0.61 & Valid \\
& Item 6 & 0.59 & Valid \\
& Item 7 & 0.66 & Valid \\
& Item 8 & 0.631 & Valid \\
& & & \\
Fartisipasi & Item 1 & 0.45 & Valid \\
& item 2 & 0.607 & Valid \\
& Item 3 & 0.542 & Valid \\
& & & \\
& Item 1 & 0.67 & Valid \\
& item 2 & 0.775 & Valid \\
& Item 3 & 0.836 & Valid \\
& Item 4 & 0.734 & Valid
\end{tabular}


Setelah selesai dilakukan uji validitas, selanjutnya dilakukan uji reliabilitas. Uji reliabilitas menguji apakah intrumen handal, yang dalam hal ini adanya konsistensi jawaban dari waktu ke waktu. Berikut hasil uji validitas

Tabel 3. Hasil Uji Validitas

\begin{tabular}{rr} 
Cronbach's Alpha & \multicolumn{1}{l}{ N of Items } \\
\hline .896 & 15
\end{tabular}

(Sumber: Data diolah)

\section{HASIL DAN PEMBAHASAN}

\section{Hasil Pengujian Awal}

Pengujian awal dilakukan untuk memastikan responden yang sesuai dengan konteks penelitian. Hal ini dilakukan dengan cara melakukan diskusi terfokus dengan kepala bagian Sumber Daya Manusia. Gambaran mengenai evaluasi kinerja diperoleh dengan diskusi tersebut adalah: (1) Penentuan responden yang sesuai dengan konteks penelitian, (2) Koreksi istilah karyawan yang awalnya disebut sebagai staf diubah menjadi istilah yang sesuai instutusi pendidikan yaitu Tenaga Kependidikan (Tendik), (3) gambaran Sistem evaluasi kinerja, dan (4) pengujian instrument penelitian.

Melihat tugas dan tanggung jawab tenaga kependidikan yaitu mendukung penyelenggaraan pendidikan di institusi pendidikan, maka penting bagi institusi untuk menilai sejauh mana tugas dan tanggung jawab telah dilaksanakan. Dengan melihat hal ini, hasil diskusi terkait responden yang sesuai dengan konteks penelitian adalah tenaga kependidikan. Hal ini diputuskan berdasarkan pertimbangan bahwa sistem evaluasi kinerja yang diuji dalam penelitian relevan dengan sistem evaluasi kinerja tenaga kependidikan. Selain itu, Sumber Daya Manusia selain tenaga kependidikan di Institusi Pendidikan Tinggi adalah tenaga pendidik yang berbeda sistem evaluasi kinerjanya, sehingga ditetapkan bahwa hanya tenaga kependidikan yang menjadi responden dalam penelitian.

Dalam sistem evaluasi kinerja tenaga kependidikan di Perguruan Tinggi, aspek yang menjadi penilaian masih di tataran perilaku. Kinerja tidak dinilai berdasarkan capaian tertentu yang ditetapkan. Bahkan penentuan target bagi individu dilakukan hanya untuk memastikan selesainya pekerjaan sesuai dengan tenggat waktu yang ditentukan. Oleh sebab itu, pemberian bonus sebagai bentuk penghargaan juga tidak berdasarkan output pekerjaan yang menjadi penilaian.

Saat ini, kondisi di institusi, bagian PSDM sedang dalam tahap merencanakan penetapan standar kinerja yang diturunkan dari target capaian institusi. Sampai dengan saat ini, PSDM masih dalam tahap membuat indikator kinerja individu yang berbasis tupoksi (tugas pokok dan 
fungsi) dengan target berbentuk luaran dokumen sebagai bukti atas pelaksanan pekerjaan sesuai prosedur, tapi bukan atas kualitas dan kuantitas pelaksanaannya. Terkait dengan target setting dalam pelaksanaan tugas tenaga kependidikan, sudah disosialisasikan dan disikusikan bersama PSDM. Namun, di masing-masing unit dapat menentukan sendiri penentuan target kerja, dengan pimpinan unit kerjanya. Hal ini terjadi karena tidak ada sistem khusus untuk menentukan target kerja.

\section{Hasil Pengujian Hipotesis}

Penelitian ini menguji apakah proses evaluasi kinerja mempengaruhi persepsi keadilan prosedural. Untuk menguji hipotesis, penelitian ini menggunakan analisis regresi. Sebelum menguji hipotesis, pengujian dilakukan untuk memastikan bahwa asumsi yang melekat pada regresi terpenuhi. Pengujian yang dilakukan dalam penelitian ini meliputi pengujian normalitas, homogenitas varians residual, dan kesesuaian model. Hasil pengujian ini menunjukkan bahwa asumsi inheren model yang digunakan divalidasi.

\section{Tabel 4. Uji Asumsi}

\begin{tabular}{l|lll} 
& Formality & Voice & Procedural Fairness \\
\hline Asymp, Sig (2-tailed) & .630 & .343 & .059 \\
VIF & 1.172 & .853 &
\end{tabular}

(Sumber: Data diolah)

Seperti yang terlihat pada tabel 4, nilai signifikansi untuk semua variabel di atas 5\%, ditunjukkan bahwa data pada semua variabel didistribusikan secara normal. Variance inflation factor (VIF) dilakukan untuk menguji apakah multikolinearitas terjadi. Multikolinearitas terjadi saat nilai VIF lebih dari 10 (Hair, dkk, 2010). Hasil seperti yang disajikan pada Tabel 1 menunjukkan bahwa multikolinearitas antar variabel tidak terdeteksi.

Setelah melakukan uji asumsi, maka langkah selanjutnya adalah pengujian hipotesis dengan menggunakan analisis regresi. Hipotesis penelitian menyatakan bahwa $\mathrm{H}_{1}$ formalitas evaluasi kinerja mempengaruhi procedural fairness, dan $\mathrm{H}_{2}$ menyatakan partisipasi dalam evaluasi kinerja mempengaruhi procedural fairness. Untuk menguji hipotesis, analisis regresi menggunakan persamaan regresi sebagai berikut:

$Y=\beta_{0}+\beta_{1} X_{1}+\beta_{2} X_{2}+\varepsilon$

Di mana:

$Y=$ Procedural fairness

$\mathrm{X}_{1}=$ Formalitas

$\mathrm{X}_{2}=$ Partisipasi 
Berikut tabel ringkasan hasil analisis regresi,

Tabel 5. Hasil Analisis Regresi

\begin{tabular}{l|lrrr}
\multicolumn{1}{c}{ Variable } & Coefficient & Value & \multicolumn{1}{c}{$t$} & $p$ \\
\hline Constant & $\beta_{0}$ & -.894 & -.326 & .746 \\
Formalitas & $\beta_{1}$ & .430 & 4.991 & .000 \\
Partisipasi & $\beta_{2}$ & .240 & 1.139 & .261 \\
F-value & & 17.918 & & .000 \\
Adjusted $R^{2}$ & & .424 & &
\end{tabular}

Berdasarkan Tabel 5, dengan menggunakan tingkat signifikansi 0.05 hasil uji masing-masing hipotesis adalah sebagai berikut. Hipotesis pertama yang menyatakan bahwa ada pengaruh formalitas terhadap procedural fairness terdukung dengan dengan nilai $p=.000$. Hipotesis kedua yang menyatakan bahwa partisipasi dalam evaluasi kinerja berpengaruh terhadap procedural fairness tidak terdukung. Hal ini dilihat dari nilai $\mathrm{p}=.261$.

\section{Pembahasan}

Hasil uji hipotesis pertama sejalan dengan penelitian Desriani \& Sholihin (2012) yang menyatakan bahwa tingkat formalitas kinerja merupakan karakteristik yang relevan untuk menciptakan persepsi procedural fairness. Sejalan dengan hasil penelitian Hartmann \& Slapnicar (2012) yang mengatakan bahwa formalitas dalam evaluasi kinerja mempengaruhi persepsi procedural fairness dalam kondisi tingkat ketidakpastian yang rendah (low task uncertainty level). Namun, penelitian Hartmann \& Slapnicar (2009) mengisyaratkan bahwa tingkat formalitas tidak berdampak positif terhadap persepsi procedural fairness. Hasil uji hipotesis kedua tidak sejalan dengan penelitian Hartmann \& Slapnicar (2012), yang mengisyaratkan bahwa partisipasi dalam proses evaluasi kinerja (voice) berpengaruh terhadap persepsi procedural fairness dalam kondisi tingkat ketidakpastian tinggi.

Hasil penelitian ini menunjukkan bahwa formalitas dalam evaluasi kinerja masih menjadi hal yang penting bagi individu ketika mempersepsikan fairness dalam proses evaluasi. Hal ini sejalan dengan penelitian (Lau \& Moser (2008) yang mengisyaratkan bahwa penting bagi organisasi untuk tetap menjaga keadilan (fairness) dalam tempat kerja yang dalam hal ini terkait dengan evaluasi kinerha karyawan. Dan, melalui formalitas evaluasi kinerja, diharapkan manajemen dapat memastikan bahwa proses evaluasi didesain secara fair. Dengan demikian, dapat meningkatkan perilaku yang baik dari karyawan.

Di sisi lain, proses evaluasi kinerja yang melibatkan partisipasi bawahan tidak berpengaruh terhadap persepsi procedural fairness. Dalam penelitian Hartmann \& Slapnicar (2012), 
mengatakan bahwa partisipasi mempengaruhi procedural fairness pada kondisi tertentu. Penelitian akuntansi manajemen mengatakan bahwa partisipasi dalam penyusunan anggaran berperan dalam hal mengurangi asimetri informasi antara atasan dan bawahan. Dalam konteks evaluasi kinerja, pertisipasi diharapkan juga dapat berperan dalam hal yang sama. Jika asimetri informasi berkurang antara atasan dan bawahan, diharapkan bawahan dapat memiliki persepsi positif tentang procedural fairness. Hasil yang tidak mendukung hipotesis ini dapat dipandang dari sisi organisasi. Tenaga kependidikan yang menjadi responden dalam penelitian ini merasa bahwa bukan dari proses evaluasi yang dalam hal ini adalah partisipasi bawahan yang membuat bawahan memiliki persepsi fair, namun dari instrumennya itu sendiri. Asumsi lain adalah bahwa responden memiliki anggapan bahwa partisipasi dalam evaluasi kinerja tidak akan mengubah hasil penilaian, karena ada pendapat bahwa hasil akhir evaluasi semata-mata di tangan atasan.

Bersadarkan hasil penelitian ini, maka implikasi praktis adalah bahwa proses evaluasi kinerja perlu diformalkan agar individu dalam organisasi merasa bahwa proses evaluasinya fair. Bentuk formal dalam evaluasi kinerja dalam hal ini adalah adanya evaluasi kinerja yang tersistematis. Namun, proses yang tersistematis tersebut tidak cukup jika tidak diimbangi dengan instrumen evaluasi yang dinilai fair. Dalam hal ini instrumen evaluasi mengandung indikator-indikator yang yang tidak hanya menilai perilaku namun juga proses dan hasil kerja. Sehingga, proses evaluasi kinerja dapat meningkatkan persepsi procedural fairness yang menurut Hartmann \& Slapnicar (2012) dapat menjadi luaran perilaku individu di tempat kerja seperti motivasi, komitmen dan kinerja tugas.

\section{SIMPULAN DAN SARAN}

Tujuan penelitian adalah menguji apakah proses evaluasi kinerja yang dalam hal ini formalitas dan partisipasi berpengaruh terhadap persepsi keadilan prosedural. Penelitian dilakukan di Universitas Ma Chung sebagai salah satu instutusi pendidikan yang menyelenggarakan Pendidikan Tinggi. Dalam menunjang penyelenggaraan pendidikan, sebuah instutusi memerlukan kerjasama yang baik antara tenaga pendidik dan tenaga kependidikan. Untuk memastikan bahwa individu dalam institusi pendidikan telah melaksanakan tugas dan tanggungjawabnya dengan baik, maka perlu adanya suatu sistem pengendalian manajemen yang dapat memotivasi, mendorong mereka bekerja selaras dengan tujuan institusi. Salah satu mekanisma ini adalah melalui sistem evaluasi kinerja, yang dalam hal ini terkait dengan penetapan target, pengukuran kinerja dan penghargaan.

Prosedur akan dipersepsikan fair ketika konsisten sepanjang waktu dan antar individu, terbebas dari bias, akurat, berisi mekanisma untuk memperbaiki keputusan yang salah, melekat dengan konsep moralitas umum, dan mewakili pendapat individu yang terlibat. Fairness menjadi 
hal yang penting untuk memotivasi individu untuk meningkatkan kinerjanya, seperti yang telah diteliti sebelumnya. Dalam sistem evaluasi kinerja, terdapat aspek prosedural fairness karena unsur di dalamnya ada penetapan tujuan, pengukuran kinerja dan pemberian penghargaan. Oleh karena itu persepsi procedural fairness relevan untuk diuji dipengaruhi oleh variabel yang terkait dengan proses evaluasi kinerja.

Penelitian ini di tahap pengujian awal dan penyebaran kuesioner untuk tujuan pengambilan data. Hasil pengujian awal adalah modifikasi instrumen penelitian yang diterjemahkan dari Bahasa Inggris ke Bahasa Indonesia dengan menyesuaikan konteks obyek penelitian. Dalam pengujian awal juga mendapatkan gambaran mengenai bagaimana proses evaluasi kinerja di Universitas Ma Chung. Berdasarkan informasi proses evaluasi kinerja tersebut maka ditetapkan yang menjadi responden dalam penelitian ini adalah tenaga kependidikan. Hal ini dikarenakan, proses evaluasi tenaga kependidikan relevan untuk mengukur persepsi procedural fairness. Selain itu, responden tidak menggunakan tenaga pendidik yang dalam hal ini adalah dosen, karena proses evaluasi berbeda dengan tenaga kependidikan.

Hasil penelitian mengungkapkan bahwa formalitas evaluasi kinerja berpengaruh terhadap persepsi procedural fairness, dan partisipasi tidak berpengaruh terhadap persepsi procedural fairness. Hal ini mendukung penelitian Desriani \& Sholihin (2012) yang menyatakan bahwa tingkat formalitas kinerja merupakan karakteristik yang relevan untuk menciptakan persepsi procedural fairness. Sejalan dengan hasil penelitian Hartmann \& Slapnicar (2012) yang mengatakan bahwa formalitas dalam evaluasi kinerja mempengaruhi persepsi procedural fairness dalam kondisi tingkat ketidakpastian yang rendah (low task uncertainty level). Hasil uji hipotesis kedua tidak sejalan dengan penelitian Hartmann \& Slapnicar (2012), yang mengisyaratkan bahwa partisipasi dalam proses evaluasi kinerja (voice) berpengaruh terhadap persepsi procedural fairness dalam kondisi tingkat ketidakpastian tinggi. Partisipasi tidak berpengaruh karena bagi responden, instrumen yang tepat dalam menilai kinerja dalam evaluasi kinerja adalah hal yang lebih penting dibandingkan adanya partisipasi dalam evaluasi.

Beberapa keterbatasan penelitian ini menjadi peluang bagi penelitian selanjutnya untuk menguji pengaruh proses evaluasi kinerja terhadap persepsi procedural fairness. Penelitian ini menggunakan metoda survey dengan keterbatasannya. Penelitian selanjutnya dapat melakukan pengujian topik ini dengan menggunakan metode selain survei, misalnya studi eksperimen. Penelitian replikasi pada para profesional dengan latar belakang industri yang berbeda-beda juga dapat dilakukan untuk meningkatkan generalisasi hasil penelitian ini. Penelitian selanjutnya juga dapat melanjutkan penelitian ini dengan menguji aspek lain dari pengukuran kinerja, tingkat trust yang berbeda (misal intraorganisasi dan antarorganisasi, trust antar kolega dan trust antara 
atasan dan bawahan), dimensi trust, variabel munculan (outcome) lain dari trust seperti kinerja, kepuasan kerja, komitmen organisasi.

\section{DAFTAR PUSTAKA}

Colquitt, J. A., Conlon, D. E., Wesson, M. J., Porter, C. O., \& Ng, K. Y. (2001). Justice at the Millenium: A Meta-Analityc Review of 25 Years of Organizational Justice Research. Journal of Applied Psychology, 425-445.

Desriani, N., \& Sholihin, M. (2012). Pengaruh Tingkat Formalitas Evaluasi Kinerja Persepsian Terhadap Aspek Keperilakuan Manajer. Simposium Nasional Akuntansi (pp. 1-25). IAI.

Franco-Santos, M., Lucianetti, L., \& Bourne, M. (2012). Contemporary Performance Measurement System: A Review of Their Concequences and a Framework for Reserach. Management Accounting Research, 79-119.

Franco-Santos, M., Lucianetti, L., \& Bourne, M. (2012). Contemporary Performance Measurement System: A Review of Their Consequences and a Framework for Research. Management Accounting Research, 79-119.

Ghozali, I. (2000). Aplikasi Analisis Multivariate dengan Program SPSS. Semarang: Badan Penerbit Universitas Diponegoro.

Greenberg, J. (1987). A Taxonomi of Organizational Justice Theories. Academy of Management Review, 9-22.

Hall, M. (2008). The Effect of Comprehensive Performance Measurement System on Role Clarity, Psychological Empowerment and Managerial Performance. Accounting, Organizations and Society, 141-163.

Harris, J., \& Durden, C. (2012). Management Accounting Reserach: An Analysis of Recent Themes and Direction for the Future. Journal of Applied Management Accounting Research, 21-42.

Hartmann, F., \& Slapnicar, S. (2009). How Formal Performance Evaluation Affect Trust between Superior and Subordinate Managers. Accounting, Organization and Society, 34, 722-737.

Hartmann, F., \& Slapnicar, S. (2012). The Perceived Fairness of Performance Evaluation: The Role of Uncertainty. Management Accounting Reserach, 17-33.

Hopwood, A. G. (1972). An Empirical Study of the Role of Accounting Data in Performance Evaluation. Journal of Accounting Research, 10, 156-182.

Langevin, P., \& Mendoza, C. (2013). How Can Management Control System Fairness Reduce Managers' Unethical Behaviours/. European Management Journal, 31, 209-222.

Lau, C. M., \& Buckland, C. (2001). Budgeting the Role of Trust and Participation: A Research Note. ABACUS(3), 369-388.

Lau, C. M., \& Moser, A. (2008). Behavioral Effect of Nonfinancial Performance Measures: The Role of Procedural Fairness. Behavioral Research in Accounting, 55-71.

Lau, C. M., \& Sholihin, M. (2005). Financial and Nonfinancial Performance Measure: How They Affect Job Satisfaction. British Accounting Review, 43, 389-413.

Lau, C. M., Wong, K. M., \& Eggleton, I. R. (2008). Fairness of Performance Evaluation Procedures and Job Satisfaction: the Role of Outcome-Based and Non-Outcome-Based Efect. Accounting and Business Research, 121-135. 
Lindquist, T. M. (1995). Fairness as an Antecedent to Participative Budgeting: Examining the Effect of Distributive Justice, Procedural Justice and Referent Cognitions on Satisfaction and Performance. Journal of Management Accounting Research, 122-147.

Shield, J. F., \& Shield, M. D. (1998). Antecedent of Partivipative Budgeting. Accounting, Organization and Society, 49-76.

Sholihin, M., \& Pike, R. (2009). Fairness in Performance Evaluation and its Behavioral Consequences. Accounting and Business Research, 397-413.

Supriyadi. (2010). The Moderating Effect of Procedural Justice on the Effectiveness of the Balanced Scorecard in Improving Managerial Performance through Organizational Commitment. Gadjah Mada Journal of Business, 12, 415-434.

Voubem, L., Kramer, S., \& Schaffer, U. (2016). Fairness Perceptions of Annual Bonus Payment; the Effect of Subjectivity Performance Measures and the Achievement of Bonus. Management Accounting Reserach, 32-46.

Wentzel, K. (2002). The Influence of Fairness Perception and Goal Commitment on Managers' Performance in a Budget Setting. Behavioral Research in Accounting, 247-271. 